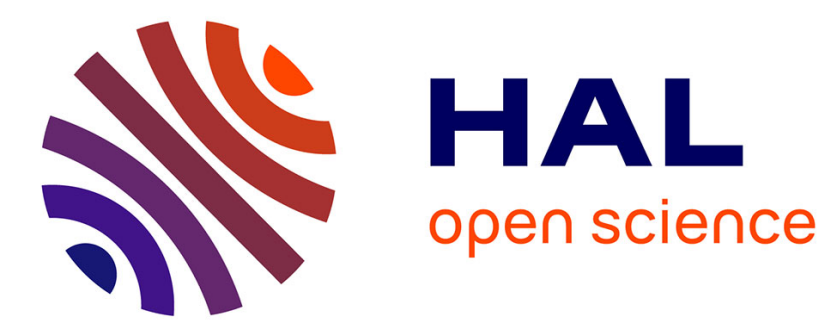

\title{
Between open access and copyright: document supply in France
}

Joachim Schöpfel

\section{To cite this version:}

Joachim Schöpfel. Between open access and copyright: document supply in France. Interlending and Document Supply, 2005, 33 (3), pp.158-161. 10.1108/02641610510618063 . sic_00001605

\section{HAL Id: sic_00001605 \\ https://archivesic.ccsd.cnrs.fr/sic_00001605}

Submitted on 22 Nov 2005

HAL is a multi-disciplinary open access archive for the deposit and dissemination of scientific research documents, whether they are published or not. The documents may come from teaching and research institutions in France or abroad, or from public or private research centers.
L'archive ouverte pluridisciplinaire HAL, est destinée au dépôt et à la diffusion de documents scientifiques de niveau recherche, publiés ou non, émanant des établissements d'enseignement et de recherche français ou étrangers, des laboratoires publics ou privés. 


\title{
Between open access and copyright: document supply in France
}

\author{
Foachim Schöpfel \\ INIST-CNRS, Vandoeuvre-lès-Nancy and University of Nancy, Nancy, France
}

\begin{abstract}
Purpose - The article aims to provide an update on the situation of document supply and interlibrary loan in France in the first months of 2005 . The main topic is open access to scientific information.

Design/methodology/approach - Describes open access, consortial purchasing, national archives, portals, electronic delivery and legal issues. Some evidence is given on the impact of electronic journals on document supply.

Findings - In the France of 2005, the legal environment and the (science, technical and medical) STM lobby continue to strengthen the position of rights-holders (publishers) and to increase restrictions and prices of access to scientific information, fixing unrealistic copyright fees around a US\$30 level.

Originality/value - Provides international interlending and document supply (ILDS) practitioners with intelligence on the current developments in interlending and document supply in France.
\end{abstract}

Keywords Portals, Electronic journals, Document delivery, Copyright law, France

Paper type Research paper

The times they are a-changin'. Since our last update on the French situation of document delivery and access to scientific information (Schöpfel, 2004a), academic and research organisations have improved their cooperation, the open access movement gathers speed and importance, new gateways offer more electronic resources than ever before, the legal environment of copyright and intellectual property is changing, and new projects of information and documentation science are emerging. This article gives an overview of the main topics of the development and tries to assess their impact on document delivery and interlending loan. However, the specific structure of Higher Education and public research in France seems too complex and heterogeneous to allow a simple and clear prognosis for the near future.

\section{Open access}

Even if the financial situation of academic and research libraries remains globally unchanged there is less "political deficit" since the CNRS (see the Appendix for a glossary of acronyms) appointed last December Laurent Romary, a researcher from the French National Institute for Research in Computer Science and Control (INRIA) as its new manager for scientific information. His main task is to define the CNRS strategy for scientific information and open access and to coordinate information politics on a national and international level.

The Emerald Research Register for this journal is available at www.emeraldinsight.com/researchregister

The current issue and full text archive of this journal is available at www.emeraldinsight.com/0264-1615.htm

Interlending \& Document Supply

$33 / 3$ (2005) $158-161$

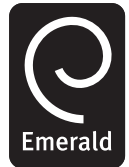

(C) Emerald Group Publishing Limited [ISSN 0264-1615] [DOI 10.1108/02641610510618063]
A first overview of the new strategy was given at the third follow-up meeting to the Berlin declaration on open access, at Southampton, 28 February to 1 March 2005. Some of the new projects are:

- The creation of institutional repositories for the major public research organisations (CNRS, INSERM, INRA and INRIA), with quality control and rich metadata.

- Research in terminology and standardization in order to improve interoperability of systems and tools. In March 2005, Nancy became the European TEI support centre.

- Creation of a national network for the scientific information in social sciences and humanities ("ADONIS") that integrates open access initiatives, epublishing, access to online collections and archives, databases, grey literature, and research on information and communication.

On 6-7 December 2005, INIST will host the 7th International Conference on Grey Literature, "Open Perspectives to Grey Resources", with Laurent Romary as inaugural speaker. Moreover, the traditional cooperation between the CNRS and the German Max-Planck Gesellschaft includes projects on open access and interoperability.

The common goal of these initiatives is to offer a wide range of free access to scientific information for the academic enduser. This, of course, impacts the need for document supply and the organisation of document supply and interlibrary loan services.

\section{Consortial purchasing and national archives}

Three major research organisations (CNRS, INSERM and INRA) and the academic consortium COUPERIN

The author thanks Magalie Collin and Hélène Prost (both from INISTCNRS) and Chérifa Boukacem (University of Lyon-1) for their helpful remarks. 
representing together nearly 70,000 academic and research staff negotiated a three-year agreement for Elsevier's Freedom Collection. The agreement comprises the use of $1,300+$ Elsevier journals for the French ILL network.

National negotiations are going on with Elsevier on Cell Press and with Thomson Scientific for the ISI Web of Science. But are these agreements really a model for future national consortial purchasing, or are they late examples for "very expensive and very restricting" (Kidd, 2003) big publishers' deals? In March, COUPERIN and research laboratories criticized the Elsevier deal as too expensive. Experience and public funding will show if big deals and specific agreements on selected resources will coexist for some time yet.

A central question of these negotiations is the indefinite access to the licensed material. Under the authority of the Ministries of Higher Education and Research, CNRS and universities started a program of national archives for digital resources that may be hosted by INIST and/or CINES.

\section{Portals}

Since 1999, INIST has launched six portals to provide CNRS and other research communities with unique entry points to scientific information (Goettmann and Gunet, 2005). The life science portal "BiblioVie" has had the greatest success in the first year receiving more than 400,000 requests by some 300 research units and becoming a reference model for other gateways (http://bibliovie.inist.fr).

This success is certainly due to the thorough selection of resources, based on need analysis and usage statistics. In 2005 , the coverage was adjusted to the expressed claims and requests of the CNRS life sciences laboratories. For 2006, INIST is preparing enhanced technology and improved search facilities, together with augmented content and a new version of its online articles catalogue. Under discussion for 2006 are a merged life and medical sciences gateway (CNRS and INSERM) and a portal for information and communication sciences and technology (CNRS and INRIA).

On 1 March 2005, the operating agent of the French academic catalogue and ILL system, ABES, launched a national portal for the academic sector (available at: www. portail-sudoc.abes.fr/). This new portal allows multisourcemulticriteria searches through a variety of bibliographic and full-text resources (databases, catalogues, archives), some with free, others with restricted access. BiomedCentral, the CCSD open archives, PCI Full Text, Elsevier's ScienceDirect, the French National Library's Gallica full text archive and the academic national union catalogue SUDOC are part of them.

Other initiatives are of more limited range and importance. The French landscape of access to electronic resources for the academic and research communities is characterized by diversity and experimental approaches (for the access to electronic theses and dissertations, see, for instance, Paillassard et al., 2004). There is need for coordination, and there is need for interoperability and standardization of data, formats and content.

\section{Impact of electronic journal access on document delivery requests}

It is generally admitted that increasing access to electronic resources results in declining demand for document delivery services, even if the empirical basis for such assertions is rather small (Kidd, 2003) and other factors are involved (Jackson, 2004; Schöpfel, 2004b). Since 1999 when COUPERIN negotiated the first nationwide academic licences, the document requests from the CNRS life sciences department dropped by more than 60 per cent. This decline was responsible for 8 per cent of the overall decrease in document delivery requests received by INIST in 2004.

Hard times for document supply. Nevertheless, even if an important part of information need is satisfied by online access to licensed or free material, another significant percentage still requires ILL and document delivery services. For instance, in 2004 the CNRS life sciences laboratories ordered through the INIST service 6,100 articles published in nearly 2,000 different serials not covered by the "BiblioVie" portal. Another 1,100 articles were ordered from backfiles that are not part of the licensed material. For financial reasons, it seems unrealistic to suppose that all of these resources will be included in future negotiations for online access.

More interesting empirical evidence for the impact of electronic journals on document supply will be published in the next few months by a research group of the university of Lyon-1 (T. Lafouge, P. Bador, C. Boukacem) that is measuring the relationship of citations, impact factor and document requests of a sample of 95 journals in pharmacological science from 1992 to 2004 .

\section{Academic interlibrary loan and document delivery}

On the 21 October 2004, two professional associations were invited to the first nationwide meeting on interlibrary loan and document supply in France. More than 100 managers of academic libraries and interlibrary loan sections attended (Schöpfel, 2005) and discussed evolving functions of libraries and related financial aspects (pricing, invoicing, financial cost-benefit analysis). These discussions are ongoing during 2005.

Probably, academic and research structures will toughen cooperation in ILL and document supply. This may result in a closer synchronization of pricing policies, resource sharing and service offer, maybe also in a greater transparency of the French marketplace in scientific information. Some major French academic libraries have already started to evaluate the option of completely free campus-wide or regional document delivery and loan. The CNRS, on the other hand has ordered a study on free document supply by INIST for its own laboratories.

One step to the closer cooperation between academic libraries and INIST was the decision of the INIST library to join the academic national union catalogue in 2005. From June 2005 on, the whole INIST collection of serials and monographs (conference proceedings, theses and dissertations, reports, reference works) will become accessible through the SUDOC portal. 


\section{Electronic document delivery}

In the meanwhile, the preparations for electronic document delivery are under way. Some academic members of the COUPERIN consortium have started to analyse the licences with STM publishers in order to evaluate the possibility of using the licensed material for electronic interlibrary loan.

INIST continues to provide secure electronic delivery from online collections on a pay-per-view basis and from its own print holdings (scan on demand). Agreements with major STM publishers should be reached in the next months, and they will modify INIST's information system, supply procedures and pricing structure. An important topic in the negotiations is the separation of requests from public institutions and the corporate sector.

\section{Legal issues}

Document supply and ILL requests need full copyright compliance. With intellectual property rights changing, delivery and loan services have to adapt, 2005 may become the year of the new legal environment in France.

The government is likely to present the new law on author's rights to the two parliaments in June (national assembly) and September (senate). The project prepared by the Ministry of Culture has already been presented in this journal (Schöpfel, 2004a). All major organizations of the library and information professionals criticized it as the "most restrictive property rights law in Europe", as a "rupture with the equilibrium between author's rights and general interest" and as "contrary to the dissemination of knowledge and cultural diversity in the digital environment" (see the site of the association of library professionals: www.abf.asso.fr). They signed an open letter to the President of the Republic (21 March 2005) and launched an online petition in favour of an "egalitarian legislation" (see http://droitauteur.levillage.org) already signed by more than 1,000 professionals (6 April 2005).

The most important argument of the professionals is that the new law excludes the exception for education and research. Their objective is to obtain a general authorisation for not-for-profit use of print and digital copies for higher education and research (see Battisti, 2004; Lahary, 2005).

Licences from the French copyright agency, the CFC, could provide shelter from the storm. However, after some legal "troubles" (Prisma Press v. CCIP) the CFC announced a radical change of function. Until 2005, the CFC represented all publishers unless they excluded themselves. From 2006 on, publishers will be excluded unless they include themselves and appear in the list of participating organisations. The CFC has already contacted about 6,000 publishers in order to obtain their agreement; up to now, there is little information about the result.

Today, the real impact of this volte-face can't be predicted. Even so, libraries and documentation services with document delivery activity have to prepare direct negotiations and agreements with those publishers that won't include themselves in the CFC list. From 2006 on, CFC and publishers' licences for print and digital material and copies will probably co-exist, a situation that will neither facilitate the work of library and information professionals nor be helpful or beneficial for the academic and scientific end-user.

Additionally the cross-border supply needs to be assessed: for example when a French academic library orders copies from SUBITO, the British Library, the CINDOC or the CISTI, which copyright applies, especially when the two national laws are quite different? What is the legal value of bilateral agreements, which is (could be) the role of the national copyright agencies? What about the international library privilege service in the digital environment? The recent cancellation of the British Library ETOC supply to SUBITO is but one indicator of the ongoing "struggle" in international document delivery.

\section{Conclusion}

Yet, we should not become fixated on the legal aspects of document supply. Scientific and academic information, particularly STM information, is a market with important revenues. Law always reflects an economic reality. Behind the interpretation of intellectual property rights are financial interests - what is the market value of articles and copies, who has to pay, what are the public structures able and willing to pay, and who receives the money?

Dissemination of scientific information is crucial for education, research and development. Document supply and interlibrary loan are part of a larger "access business" including databases, subscriptions, archives, search engines, portals, repositories etc.

In the France of 2005, the legal environment and the STM lobby continue to strengthen the position of right-holders (publishers) and to increase restrictions and prices of access to scientific information, fixing unrealistic copyright fees around a US $\$ 30$ level. Tryin' to get to heaven? Rather a "Pyrrhic victory" that contains the germs of its own defeat.

Paradoxically, the first and most significant result of increasing prices and legal restrictions in France is the reinforcement of national and international cooperation between academic and research organisations and the acceleration of the open archive movement. What will be the commercial reaction to this new reality? It would be surprising if prices and fees do not start to come down to a more realistic level.

Let us close this update with news that confirms the enthusiasm of France to shape the international cooperation of document supply: some weeks ago, IFLA nominated the head of the INIST backup library service, Jacqueline Gillet, as the new standing committee member for the Document Delivery and Interlending Section for 2005 to 2009. Good luck to Jacqueline!

\section{References}

Battisti, M. (2004), "Le droit d'auteur, un obstacle à la liberté d'information?", Bulletin des Bibliothèques de France, Vol. 49 No. 6, pp. 31-5.

Goettmann, E. and Gunet, M.C. (2005), "Portals enable national access", Research Information, No. 15, January/ February, pp. 21-2.

Jackson, M.E. (2004), "Will electronic journals eliminate the need for ILL?”, Interlending \& Document Supply, Vol. 32 No. 3, pp. 192-3.

Kidd, T. (2003), "Does electronic journal access document delivery requests? Some data from Glasgow University Library”, Interlending \& Document Supply, Vol. 31 No. 4, pp. 264-9. 
Lahary, D. (2005), "Le projet de loi sur le droit d'auteur et les droits voisins dans la société d'information: attention danger", available at: http://droitauteur.levillage.org

Paillassard, P., Schöpfel, J. and Stock, C. (2004), "How to get a French doctoral thesis, especially when you aren't French", GL6 6th International Conference on Grey Literature: Work on Grey in Progress, New York Academy of Medicine, New York, NY, 6-7 December.

Schöpfel, J. (2004a), "Transitions - news on the access to digital information in France”, Interlending $\mathcal{E}$ Document Supply, Vol. 32 No. 1, pp. 47-9.

Schöpfel, J. (2004b), "Relations entre bibliothèques universitaires et INIST-CNRS - constats et perspectives", AURA-ADBU Meeting on ILL and Document Delivery, University of Montpellier, Montpellier, 21 October, available at: http://ccsd.cnrs.fr

Schöpfel, J. (2005), "Interlibrary loan and document supply in France - the Montpellier meeting", Interlending \& Document Supply, Vol. 33 No. 1, pp. 56-8.

\section{Further reading}

Romary, L. (2005), "The way to open resources", Berlin 3 Open Access: Progress in Implementing the Berlin Declaration on Open Access to Knowledge in the Sciences and Humanities, University of Southampton, Southampton, 28 February-1 March, available at: www. eprints.org/berlin3/

\section{Glossary}

ABES: French academic bibliographic agency (www.abes.fr). CCSD: CNRS laboratory for direct scientific communication and open archives (www.ccsd.cnrs.fr).

CFC: French copyright agency (www.cfcopies.fr).

CINES: French national computer centre of higher education at Montpellier (www.cines.fr).

CNRS: French national centre for scientific research (www. cnrs.fr).

COUPERIN: French academic consortium (www.couperin. org).

INIST: CNRS institute for scientific and technical information at Nancy (www.inist.fr).

INRA: French national institute for agricultural research (www.inra.fr).

INRIA: French national institute for research in computer science and control (www.inria.fr).

INSERM: French national institute for medical research (www.inserm.fr).

SUDOC: French national academic union catalogue (http:// sudoc.abes.fr).

TEI: International Text Encoding Initiative (www.tei-c.org).

\section{About the author}

Joachim Schöpfel is Head of the library and document supply department of INIST-CNRS and a lecturer at the University of Nancy, Nancy, France. 